\title{
Estimating human toxicity potential of land application of sewage sludge: the effect of modelling choices
}

\author{
Robin Harder $^{1}$ - Gregory M. Peters ${ }^{1,2}$ • Magdalena Svanström ${ }^{1}$ - Stuart J. Khan ${ }^{2}$. \\ Sverker Molander ${ }^{3}$
}

Received: 30 October 2015 / Accepted: 5 August 2016 /Published online: 19 August 2016

(C) The Author(s) 2016. This article is published with open access at Springerlink.com

\begin{abstract}
Purpose Many municipalities are facing increasing pressure to adapt solid waste and wastewater management infrastructures in order to better close nutrient cycles. The focus of this study is on the estimation of the human toxicity potential associated with chemical contaminants released upon the application of sewage sludge to agricultural land. More specifically, this study investigated the effect of modelling choices regarding fate and exposure assessment.

Methods Monitoring data were collected for contaminants present in the sewage sludge from the wastewater treatment plant in Gothenburg and from other municipal wastewater treatment plants in Sweden. Based on these monitoring data, an overall burden of disease was estimated using characterisation factors taken from the USEtox models (versions 1.01 and 2.0). For the exposure through vegetables, an alternative
\end{abstract}

Responsible editor: Stig Irving Olsen

Electronic supplementary material The online version of this article (doi:10.1007/s11367-016-1182-x) contains supplementary material, which is available to authorized users.

Robin Harder

robin.harder@wetryharder.ch

1 Chemical Environmental Science, Department of Chemistry and Chemical Engineering, Chalmers University of Technology, 412 96 Gothenburg, Sweden

2 School of Civil and Environmental Engineering, University of New South Wales, Sydney, NSW 2052, Australia

3 Environmental Systems Analysis, Department of Energy and the Environment, Chalmers University of Technology, 412 96 Gothenburg, Sweden life cycle impact assessment (LCIA) model was developed. The intake fractions thus obtained were used in combination with human health effect factors taken from the USEtox 2.0 database. The model results were compared with the USEtox models, and whether these two versions of the USEtox model provide significantly different results was also examined. The potential relevance of accidental ingestion of sludge was also considered.

Results and discussion The different LCIA models provided burden of disease estimates that differed from one another for individual contaminants (up to five orders of magnitude). The aggregated burdens of disease (i.e. sum for all contaminants considered in this study) estimated through different model variants, however, were of the same order of magnitude. For both metals and organic contaminants, only a small set of contaminants was found to make significant contributions to the aggregate burden of disease. However, it is uncertain whether the 15 metals and 106 organic contaminants covered by this study are those of greatest health significance of all contaminants potentially present in sewage sludge.

Conclusions and recommendations The results of this study indicate that the technical information provided by the various approaches to modelling human toxicity in life cycle assessment (LCA) in the context of land application of sewage sludge management is consistent on the whole. However, given the uncertainties associated with the assessment of human toxicity in LCA, it is important to also contemplate the extent to which LCA in general is capable of informing the sewage sludge debate when it comes to human toxicity and possibly also other indicators. Future research could focus on identifying which types of questions of interest in the context of sewage management can be answered by LCA and which cannot.

Keywords Biosolids $\cdot$ Chemical risks $\cdot$ LCA $\cdot$ LCIA . USEtox 


\section{Introduction}

The use of sewage sludge to supply nutrients to agricultural land implies that a wide range of contaminants present in sludge is dispersed to agricultural soils and other parts of the environment. As a result, land application of sludge has been debated in Sweden and elsewhere for many years (see, e.g. Bengtsson and Tillman 2004 and references therein). Both inorganic (i.e. metals) and organic contaminants (e.g. industrial chemicals, pharmaceuticals and hormones) as well as pathogens contained in sludge have been causes of concerns.

In recent years, several studies were commissioned in the Nordic countries to assess the human health risks associated with the use of sludge as fertiliser for agricultural land. Among these studies were a study commissioned by the Norwegian Food Safety Authority and conducted by the Norwegian Scientific Committee for Food Safety (VKM 2009), a study commissioned by the Nordic Council of Ministers (Diana et al. 2011) and a study commissioned by the Swedish Environmental Protection Agency and the Swedish Chemicals Agency (Sternbeck et al. 2013). Repeated application of sewage sludge was predicted to lead to an increase in soil concentrations of most of the examined metals (VKM 2009; Sternbeck et al. 2013). VKM (2009) predicted that the accumulation of cadmium $(\mathrm{Cd})$ and mercury $(\mathrm{Hg})$ might result in an undesirable increase in human dietary intake, whereas Sternbeck et al. (2013) found that cadmium $(\mathrm{Cd})$, copper $(\mathrm{Cu})$ and zinc $(\mathrm{Zn})$ are contaminants that come closest to effect thresholds. The occurrence of organic contaminants in sewage sludge was generally predicted not to be of concern to either human health or the environment (VKM 2009; Diana et al. 2011; Sternbeck et al. 2013). VKM (2009) covered a range of organic contaminants and pharmaceuticals and found that only linear alkylbenzene sulfonate (LAS) and octylphenols and nonylphenols might initially exceed effect levels regarding ecotoxicity in agricultural soil but degrade rapidly to levels below concern. Sternbeck et al. (2013) also examined a range of organic contaminants and expressed concern about the potential for low but persistent perfluorooctane sulfonate (PFOS) contamination.

The three abovementioned studies were all conducted under a risk assessment (RA) framework. The assessment of risks to human health consisted of a comparison of the predicted intake of contaminants by certain organisms with corresponding intake thresholds. This threshold comparison formed the basis for evaluating whether the risks to individual organisms should be deemed acceptable. Yet, there is an additional perspective in the sewage sludge debate worth considering. An interesting and relevant question is whether the impact on human health related to chemical contaminants, on the basis of a given human population as a whole, is greater or lesser for one sewage sludge management option (e.g. application of sewage sludge to agricultural land) than for another (e.g. incineration of sewage sludge with subsequent phosphorus recovery). Also, it would be of interest to find out whether the comparison of individual exposures with corresponding thresholds and the overall impact associated with the exposure of a whole population point towards a similar set of chemical contaminants of concern (Lim et al. 2011) or to consider tradeoff relationships between local impacts related to chemical contaminants or pathogens and global impacts related to other stressors (Kobayashi et al. 2015).

The focus of this study is on the estimation of the human toxicity potential associated with chemical contaminants released upon the application of sewage sludge to agricultural land in terms of a burden of disease in disability-adjusted life years (DALYs). DALYs are a measure of overall disease burden that was developed in the 1990s by WHO (Murray 1994). The human toxicity potential related to chemical contaminants in sludge has been estimated in previous life cycle assessment (LCA) studies using generic life cycle impact assessment (LCIA) models such as USES-LCA (Heimersson et al. 2014; Hospido et al. 2010; Lane et al. 2015) and USEtox (Yoshida et al. 2014). Other LCA studies relied on LCIA models tailored to the given specific context of land application. For instance, Sablayrolles et al. (2010) assessed the environmental impacts of land application of two types of sewage sludge (i.e. dried and composted) with a particular emphasis on human toxicity via plant ingestion. The respective impact score for human toxicity via plant ingestion was expressed in terms of the sum of the risk factor (i.e. exposure dose divided by limit dose) per contaminant multiplied by its emission per functional unit. Nakakubo et al. (2012) compared alternative technologies for the disposal of sewage sludge and food waste, amongst others with regards to risks to public health via crop ingestion. The respective impact score for human health risks was expressed in terms of DALYs and included six metals. LCIA models have also been used outside the LCA framework, for example, to identify the pollutants contained in wastewater that have the highest ecotoxicity and human toxicity effects (Muñoz et al. 2008), to calculate a toxicity-extended ecological footprint of water services (Peters et al. 2008) or to identify which substances emitted from industry, households, service production and agriculture give rise to the highest ecotoxicity and human toxicity effects and which products and emission pathways have the largest share in these effects (Mattila et al. 2011).

The aim of the present study is to estimate the human toxicity potential associated with a comprehensive land application scenario for the municipal wastewater treatment plant in Gothenburg, Sweden. Gothenburg was chosen as case study site because the municipality of Gothenburg and the local wastewater treatment plant operator are currently investigating a range of future sewage sludge management options. For the estimation of the human toxicity potential, we primarily relied on the USEtox consensus model. USEtox 1.01 is the 
version used in the European Product Environmental Footprint standard (EC 2013/179/EU), while little has been published examining the update, USEtox 2.0, as it was only released in August 2015. Since the newer version USEtox 2.0 has only recently been released, we aimed to provide one of the first case studies to examine whether results obtained using the new version differ significantly from the older version USEtox 1.01. Additionally, as previous LCA studies on sludge management (Nakakubo et al. 2012; Sablayrolles et al. 2010) focused primarily on human toxicity via plant ingestion, we aimed to extend this comparison and also investigate an LCIA model tailored specifically to the context of land application of sewage sludge and based on the fate and exposure models underpinning previous RA studies.

\section{Methods}

The model calculations underpinning this study are based on the generic LCIA models USEtox 1.01 (Rosenbaum et al. 2011) and USEtox 2.0 (Fantke et al. 2015) and an alternative LCIA model termed sludge land application (SLAtox). The latter was based on the mathematical relationships described in the European Chemicals Bureau Technical Guidance Document (TGD) on Risk Assessment (ECB 2003) and commonly used in RA studies of land application of sewage sludge (VKM 2009; Diana et al. 2011; Sternbeck et al. 2013). The USEtox models were used to obtain characterisation factors (CFs), which were then applied to the emissions of chemical contaminants resulting from the application of sludge to agricultural land. The SLAtox model was used to estimate intake fractions (iFs), which were then applied together with effect factors (EFs) from USEtox 2.0 to the emissions of chemical contaminants resulting from the application of sludge to agricultural land.

\subsection{Model description}

\subsubsection{Calculations based on the USEtox models}

The USEtox models describe the toxic impacts of chemical contaminants released to the environment on humans and freshwater aquatic organisms. The environmental fate submodel is a multimedia model consisting of a range of homogeneous compartments at three geographical scales (i.e. urban, continental and global) and each representing a specific part of the environment (e.g. air, water, soil). The fate submodel accounts for removal processes and intermedia transport processes and represents steady-state conditions. The exposure pathways (for human toxicity) covered in the USEtox models are related to the compartments air, drinking water, aboveground produce (in USEtox 2.0 terminology or "exposed produce" in USEtox 1.01 terminology), belowground produce (in USEtox 2.0 terminology or "unexposed produce" in USEtox 1.01 terminology), meat, dairy and fish. Some of the exposure pathways are not applicable in the context of this study, however. For instance, in Sweden, it is illegal to spread sewage sludge on grazing land. For a detailed description of the USEtox models, the reader is referred to the literature (Rosenbaum et al. 2008; Rosenbaum et al. 2011; Fantke et al. 2015). The USEtox calculations were performed based on the USEtox models downloaded from the USEtox homepage (www.usetox.org).

Four sets of CFs were obtained based on the USEtox models. That is, each USEtox model version (i.e. USEtox 1.01 and USEtox 2.0, respectively) was run with two parameterisations. The first parameterisation corresponds with the default parameterisation; the second parameterisation consists of model parameters modified with intent to reflect the local conditions (i.e. Västra Götaland County) to the extent feasible. The parameter values used are provided in Table S1 in Online Resource 1 (Electronic Supplementary Material).

The potential burden of disease related to the metals and organic contaminants contained in sewage sludge applied to agricultural land was calculated as shown in Eq. 1. Values shown in parentheses for the disease burden per case were taken from EC (2010).

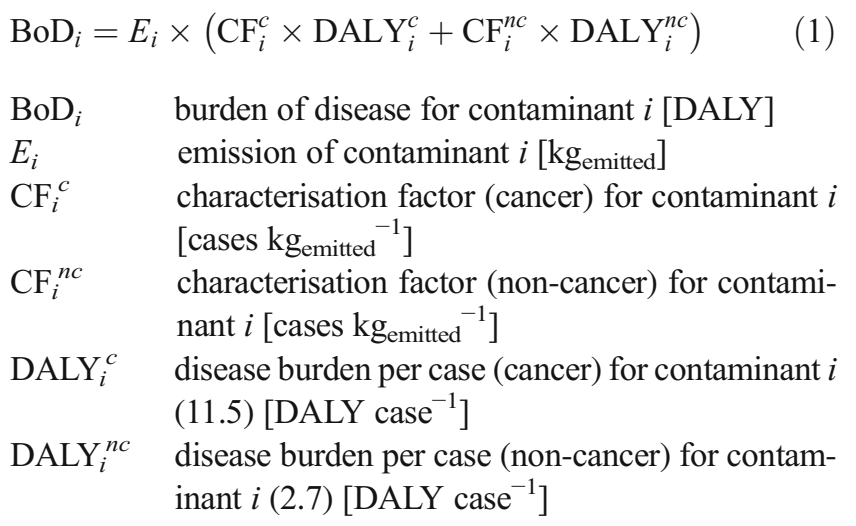

\subsubsection{Calculations based on the SLAtox model}

The SLAtox model addresses only the uptake of chemical contaminants through agricultural produce. The SLAtox model is based on the assumption of steady state in the soil compartment. That is, the amount of a given contaminant added to the soil $\left(E_{i}\right)$ is assumed to be equal to the amount removed through loss processes such as volatilisation, leaching, degradation and plant uptake. The intake fraction of a given contaminant $\left(\mathrm{iF}_{i}\right)$ through ingestion of agricultural produce was calculated as the fraction of plant uptake relative to all loss processes, furthermore allowing for food losses (i.e. edible produce lost between harvest and retail) and food waste (i.e. edible produce wasted in retail and by final consumers) (Eq. 2). The first-order rate constants for biodegradation were 
taken from the USEtox 2.0 database. Values shown in parentheses were chosen by the authors. The first-order rate constants for plant uptake, leaching and volatilisation were calculated based on ECB (2003) and VKM (2009) according to Equations S1 to S5 in Online Resource 1 (Electronic Supplementary Material).

$\mathrm{iF}_{i}=f_{\mathrm{fl}} \times f_{f w} \times \frac{k_{\text {plant }}}{k_{\text {plant }}+k_{\text {volat }}+k_{\text {leach }}+k_{\text {biodeg }}}$

$\mathrm{iF}_{i} \quad$ intake fraction for contaminant $i\left[\mathrm{~kg}_{\text {intake }} \mathrm{kg}_{\text {emitted }}{ }^{-1}\right]$

$f_{\mathrm{fl}} \quad$ food loss factor $(0.9)[-]$

$f_{\text {fw }} \quad$ food waste factor $(0.7)[-]$

$k_{\text {biodeg }} \quad$ first-order rate constant for biodegradation in topsoil (USEtox 2.0 database) $\left[\mathrm{day}^{-1}\right]$

$k_{\text {plant }} \quad$ first-order rate constant for plant uptake from topsoil (Equation S1) [day ${ }^{-1}$ ]

$k_{\text {leach }} \quad$ first-order rate constant for leaching from topsoil (Equation S2) [day ${ }^{-1}$ ]

$k_{\text {volat }}$ first-order rate constant for volatilisation from topsoil (Equation S3) [day ${ }^{-1}$ ]

The iFs obtained through the SLAtox model were used in combination with human health EFs taken from the USEtox 2.0 database and applied to the emissions of chemicals resulting from the application of sewage sludge to agricultural land as shown in Eq. 3. Values shown in parentheses for the disease burden per case were taken from EC (2010).

$\mathrm{BoD}_{i}=E_{i} \times \mathrm{iF}_{i}\left(\mathrm{EF}_{i}^{c} \times \mathrm{DALY}_{i}^{c}+\mathrm{EF}_{i}^{n c} \times \mathrm{DALY}_{i}^{n c}\right)$

$\mathrm{BoD}_{i} \quad$ burden of disease for contaminant $i$ [DALY case ${ }^{-1}$ ]

$E_{i} \quad$ emission of contaminant $i\left[\mathrm{~kg}_{\mathrm{emitted}}\right]$

$\mathrm{iF}_{i} \quad$ intake fraction for contaminant $i$ (Equation 2) $\left[\mathrm{kg}_{\text {intake }} \mathrm{kg}_{\text {emitted }}{ }^{-1}\right]$

$\mathrm{EF}_{i}^{c} \quad$ effect factor (cancer) for contaminant $i$ (USEtox 2.0 database) [cases $\mathrm{kg}_{\text {intake }}{ }^{-1}$ ]

$\mathrm{EF}_{i}^{n c} \quad$ effect factor (non-cancer) for contaminant $i$ (USEtox 2.0 database) [cases $\mathrm{kg}_{\text {intake }}{ }^{-1}$ ]

DALY $_{i}^{c}$ disease burden per case (cancer) for contaminant $i$ (11.5) [DALY case $^{-1}$ ]

$\mathrm{DALY}_{i}^{n c}$ disease burden per case (non-cancer) for contaminant $i(2.7)\left[\mathrm{DALY}\right.$ case $\left.^{-1}\right]$

The SLAtox model was implemented in Microsoft Excel 2011. For metals, the SLAtox model distinguished between two types of crops: root crops (belowground produce) and leafy crops (aboveground produce). To avoid double counting, it was assumed that half of the sludge is put on agricultural land where aboveground produce is grown and half of the sludge is put on agricultural land where belowground produce is grown. For organic contaminants, bioconcentration factors (BCFs) were available only for belowground produce. Therefore, it was assumed that all of the sludge is put on agricultural land where belowground produce is grown. For some metals (e.g. arsenic, chromium, antimony), the USEtox database provided EFs for two different oxidation states. As the monitoring data did not make such a distinction, we considered both oxidation states in the calculation of disease burden for individual metals. To avoid double counting, it was assumed that half of the respective metal was present in each of the two respective oxidation states.

\subsubsection{Accounting for accidental ingestion of sewage sludge}

In LCA, it is a common practice to base the comparison of the performance of different product or service systems, or different life cycle phases of a product or service system, on a typical situation when technical systems operate according to the design specifications. Because of a significant variability in the procedures and locations used for sewage sludge management, RA studies often include occupational, recreational, as well as residential exposure pathways. In the context of sewage sludge management, the frequency of the occurrence of operating conditions where the system does not work according to the design specifications may warrant consideration of non-routine operation scenarios in LCA. In this study, we estimated the amount of treated sewage sludge accidentally ingested that would lead to a disease burden equal to the disease burdens estimated by the USEtox and SLAtox models.

\subsection{Data sources and data availability}

The concentrations (averages of the years 2012-2014) of metals and organic contaminants in sewage sludge were obtained from the local wastewater treatment plant operator in Gothenburg (Gryaab AB) and represent regular monitoring data. Measured concentrations were available for 62 metals and 340 organic contaminants in the sewage sludge of Gothenburg. The local monitoring data for organic contaminants were complemented with monitoring data (for the years 2000-2013) from other Swedish wastewater treatment plants in order to increase the coverage of organic contaminants (Naturvårdsverket 2015), which yielded measured concentrations for an additional 243 organic contaminants.

Of the contaminants for which monitoring data were available, only a fraction could be considered in the model calculations, as for the majority of the contaminants, human health EFs and BCFs were not available. Human health EFs and BCFs (both for root vegetables and leafy vegetables) were available in the USEtox databases (USEtox 1.01 and USEtox 2.0) for 15 out of the 62 metals for which monitoring data were available. For organic contaminants, human health EFs were also taken from the USEtox databases (USEtox 1.01 or USEtox 2.0, depending on the model variant), whereas BCFs were taken from Diana et al. (2011). The availability 
of EFs and BCFs for organic contaminants is summarised in Fig. 1. The model variant with the most comprehensive coverage of organic contaminants (USEtox 2.0) included 106 out of the 583 organic contaminants for which monitoring data were available.

The contaminant concentrations underlying the calculations performed in this study are provided in Tables S2 and S3 in Online Resource 1 (Electronic Supplementary Material). The BCFs underlying the calculations are provided in Table S4 in Online Resource 1 (Electronic Supplementary Material).

\section{Results}

The aggregated burdens of disease related to metals and organic contaminants and estimated through the different model variants are summarised graphically in Fig. 2. The actual values are provided in Table S5 in Online Resource 1 (Electronic Supplementary Material). The detailed results per individual contaminant are presented in Online Resource 2 (Electronic Supplementary Material).

\subsection{The effect of modelling choices}

\subsubsection{Differences between the USEtox 1.01 and USEtox 2.0 models}

The differences at the level of individual contaminants between different combinations of USEtox model variant (i.e. USEtox 1.01 and USEtox 2.0) and parameterisation (i.e. default and user-defined parameterisation) are presented in Fig. 3 for the 15 metals and 106 organic contaminants included. For both the USEtox 1.01 and USEtox 2.0 models, the choice between the default parameterisation and the userdefined parameterisation had little effect (see Fig. 3a-d). This was also evident when looking at the aggregated burdens of disease (see Fig. 2). The respective aggregated burdens of disease differed no more than a factor 2 from one another for metals and no more than a factor 5 for organic contaminants
EFs and BCFs

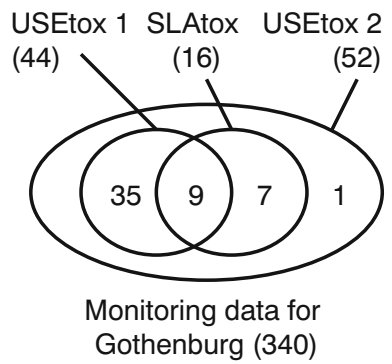

EFs and BCFs

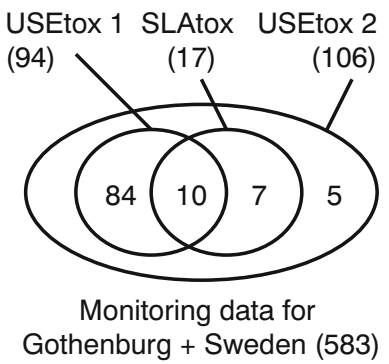

Fig. 1 Number of organic chemicals for which monitoring data on measured concentrations in sludge, human health effect factors $(E F S)$ and bioconcentration factors $(B C F s)$ were available (see Table S5 in Online Resource 1, Electronic Supplementary Material). For both the default parameterisation and the userdefined parameterisation, the USEtox 2.0 model, for most metals and organic contaminants, showed a tendency to estimate higher burden of disease estimates at the level of individual contaminants than the USEtox1.01 model (see Fig. 3eh). For organic contaminants, this tendency was also apparent from the aggregated burden of disease estimates, as the aggregated burden of disease estimates obtained from the USEtox 2.0 model were two orders of magnitude larger than the overall burden of disease estimates obtained from the USEtox 1.01 model (see Fig. 2 and Table S5 in Online Resource 1, Electronic Supplementary Material). For metals, however, this tendency was not confirmed by the aggregated burden of disease estimate, as the aggregated burden of disease estimate was larger for the USEtox 1.01 model compared with the USEtox 2.0 model (see Fig. 2 and Table S5 in Online Resource 1, Electronic Supplementary Material). The reason is that there was one dominant metal (zinc) determining the magnitude of the aggregated burden of disease estimate, and for this dominant metal, the overall tendency did not hold (see Fig. 3e-f).

The differences between the USEtox 1.01 and USEtox 2.0 models were investigated in detail for the default parameterisation (see Fig. 4). The USEtox 2.0 model calculated a larger iF (aggregate over all exposure pathways) than the USEtox 1.01 model for all metals but chromium(III) and for the majority (67 out of 94) of organic contaminants (see Fig. 4a). The human health EFs were identical in the USEtox 1.01 and USEtox 2.0 models for all metals but zinc(II) and for all but seven organic contaminants (see Fig. 4b). The burden of disease estimates (DALY) were larger in the USEtox 2.0 model than in the USEtox 1.01 for all metals but chromium(III) and zinc(II) and for the majority (67 out of 94) of organic contaminants (see Fig. 4c). In absolute numbers, only few contaminants significantly influenced the burden of disease ( $\triangle \mathrm{DALY}$ ) (see Fig. 4d). Regarding metals, chromium(VI) led to the largest increase of disease burden from the USEtox 1.01 to the USEtox 2.0 model, and zinc(III) led to an even larger decrease (see Fig. 4d), so that the aggregate burden of disease estimated by the USEtox 2.0 model was lower than the one estimated by the USEtox 1.01 model (see Fig. 2). Three organic contaminants covered in both the USEtox 1.01 and USEtox 2.0 models could explain $30 \%$ of the increase of the aggregate burden of disease estimate from USEtox 1.01 to USEtox 2.0 (see Fig. 4d). The remaining $70 \%$ of the increase from USEtox 1.01 to USEtox 2.0 originated from the availability of EFs for 12 more organic contaminants in the USEtox 2.0 model compared to the USEtox 1.01 model, of which 5 were the main contributors to the increase (see Fig. 4d).

Another interesting observation relates to the distinction between cancer and non-cancer effects (see Table S5 in 


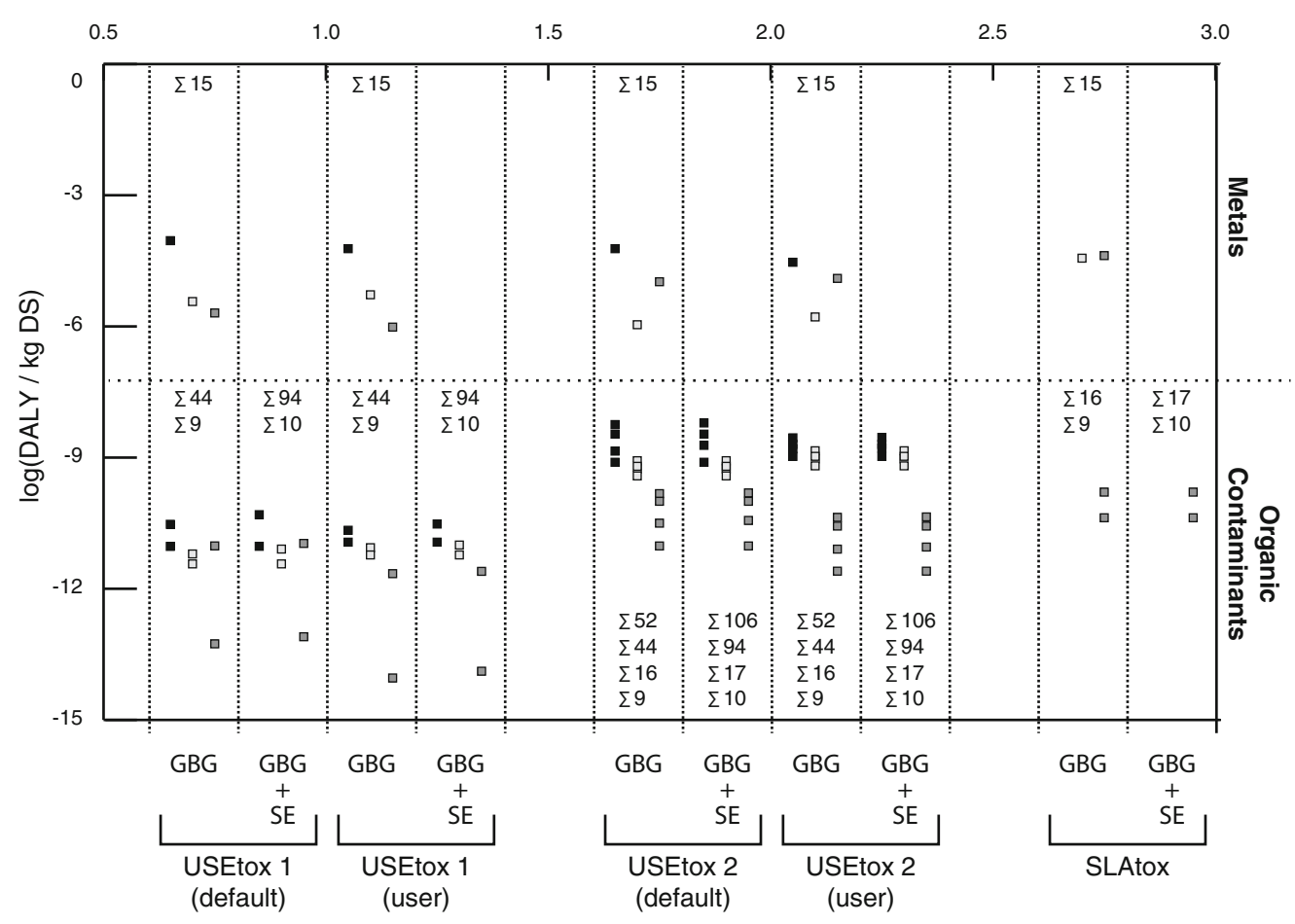

all exposure pathways (also other than agricultural produce) (USEtox)

$\square$ exposed produce (USEtox 1) OR above ground produce (USEtox 2) OR leaf (SLAtox)

$\square$ unexposed produce (USEtox 1) OR below ground produce (USEtox 2) OR root (SLAtox)

Fig. 2 The effect of modelling choices on the aggregated burden of disease. $G B G$ denotes that only monitoring data from Gothenburg were used in the calculations. $G B G+S E$ denotes that the monitoring data from Gothenburg were complemented with monitoring data from other wastewater treatment plants in Sweden. Numbers preceded by the sum sign $(\Sigma)$ indicate the number of contaminants included in the respective aggregate burden of disease. Note that for organic contaminants, several aggregates are presented (see Fig. 1 for more details)
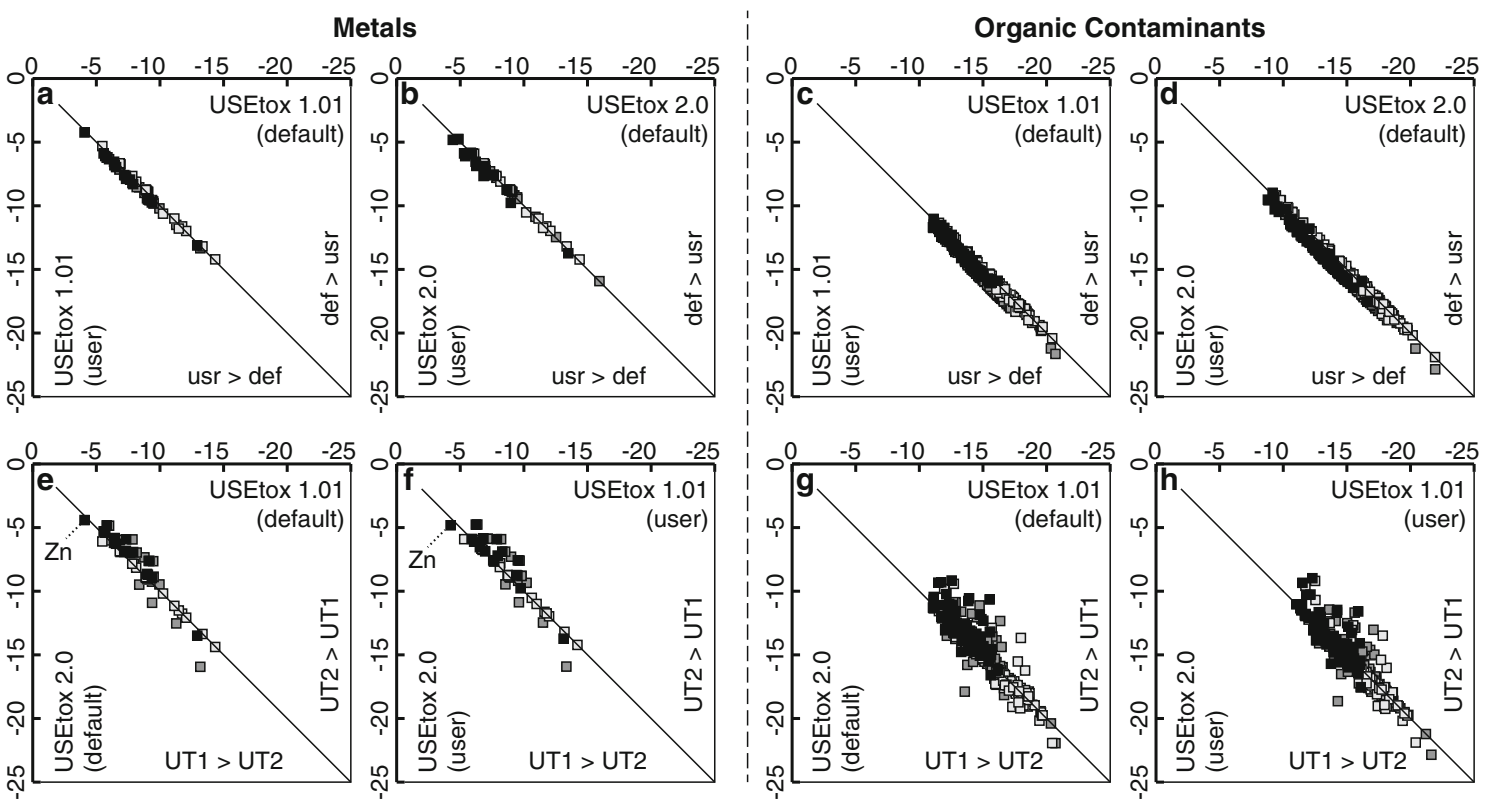

- all exposure pathways (also $\square$ exposed produce (USEtox 1.01) OR other than agricultural produce) above ground produce (USEtox 2.0)

- unexposed produce (USEtox1.01) OR below ground produce (USEtox 2.0)

Fig. 3 Differences at the level of individual contaminants between different combinations of USEtox model variant (i.e. USEtox 1.01 and USEtox 2.0) and parameterisation (i.e. default and user-defined parameterisation). The units on all axes are DALY per kg DS 

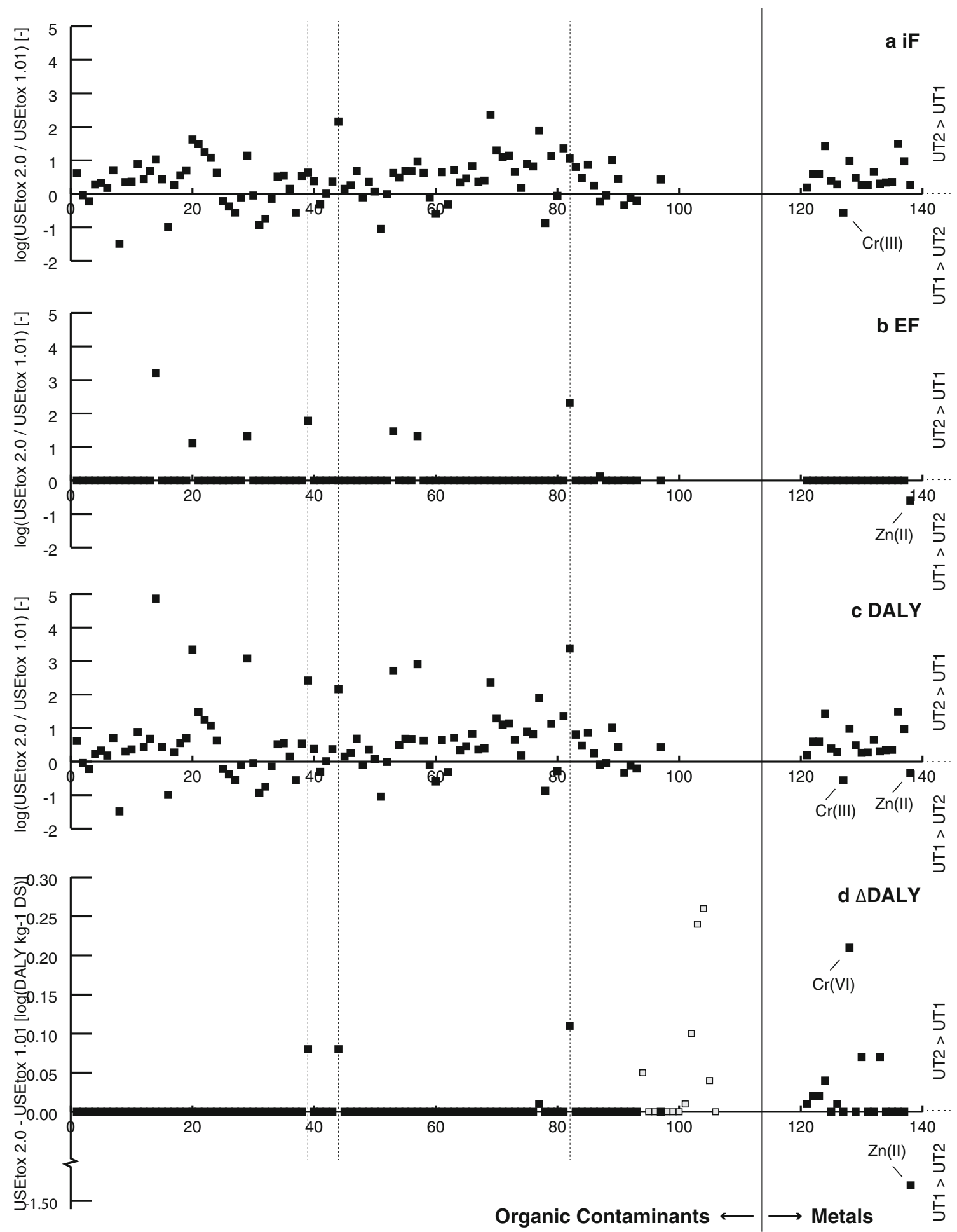

Fig. 4 Differences between the USEtox 1.01 and the USEtox 2.0 models. Monitoring data for Gothenburg as well as other treatment plants in Sweden was considered (i.e. GBG $+\mathrm{SE}$ ). The respective values per individual chemical contaminant are ordered in the sequence

Online Resource 1, Electronic Supplementary Material). For metals, both in the USEtox 1.01 and USEtox 2.0 models, close to $100 \%$ of the aggregate burden of disease are non-cancer effects. For organic contaminants, in the USEtox 1.01 model, of occurrence of the chemical contaminants in the USEtox 2.0 database. Black squares represent contaminants with EFs available in both USEtox 1.01 and USEtox 2.0. Grey squares represent contaminants with EFs available only in USEtox 2.0

the contributions of cancer and non-cancer effects to the aggregate burden of disease are of the same order of magnitude. In the USEtox 2.0 model, however, close to $100 \%$ of the aggregate burden of disease for organic contaminants are 
cancer effects. The reason for the dominance of cancer effects in the USEtox 2.0 model is that the EFs for the 12 additional organic contaminants added to the USEtox 2.0 database only cover cancer effects. Also, cancer EFs were added in USEtox 2.0 for some of the organic contaminants where only noncancer EFs were available in USEtox 1.01, or cancer EFs were increased in USEtox 2.0 as compared to USEtox 1.01.

\subsubsection{Differences between the SLAtox and the USEtox 2.0 models}

As the SLAtox model used the same chemical and biological data as the USEtox 2.0 model (notably the EFs for use in the SLAtox model were taken from the USEtox 2.0 database), the variations found in this study between the SLAtox and the USEtox 2.0 model originated from differences in fate and exposure modelling and not in effect assessment. For metals, the differences between the SLAtox and USEtox 2.0 models (for exposure through aboveground and belowground produce only) were larger than the differences between any of the USEtox variants, as indicated by the larger spread in Fig. 5a compared to Fig. 3a/b, e/f. For both metals and organic contaminants, the SLAtox model showed a general tendency to provide higher burden of disease estimates than the USEtox 2.0 model when only exposure through aboveground and belowground produce was compared (see Figs. 2 and 5).

The differences between the USEtox 2.0 model (default parameterisation) and the SLAtox model results were investigated in detail (see Fig. 6). For both metals and organic contaminants, the SLAtox model (average for root and leaf vegetables) estimated lower burdens of disease than the USEtox 2.0 model (only for the exposure pathways related to aboveground and belowground produce) for some contaminants and higher burdens of disease for other contaminants (see Fig. 6a). In absolute numbers, only a few contaminants significantly

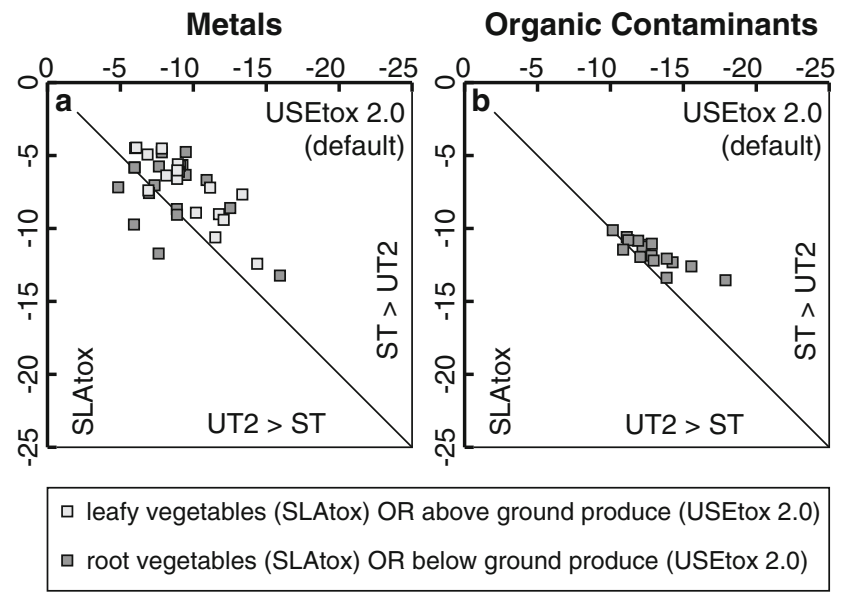

Fig. 5 Differences at the level of individual contaminants between the USEtox 2.0 model (default parameterisation) and the SLAtox model. The units on all axes are DALY per $\mathrm{kg}$ DS influenced the burden of disease ( $\triangle \mathrm{DALY}$ ) (see Fig. $6 \mathrm{~b}$ ). Four metals and three organic contaminants were dominant in determining the differences between the SLAtox model and the USEtox 2.0 model (default parameterisation) (see Fig. 6b).

\subsection{Dominant metals and organic contaminants}

Figures 3 and 4 indicate that some chemical contaminants lead to a higher burden of disease than others. We investigated which of the metals considered in this study contribute more than $10 \%$ of the aggregated burden of disease for metals in at least one of the tested model variants. A closer look at the results presented in Table S6 in Online Resource 1 (Electronic Supplementary Material) revealed that four metals are potentially dominant: chromium, mercury, lead and zinc. Table S7 in Online Resource 1 (Electronic Supplementary Material) further specifies whether it is the concentration in the sludge, the iF or the EF that explains the dominance. For the organic contaminants, the disease burden estimates for the individual organic contaminants were ordered from largest to smallest for each model version. The cumulative sums thus obtained are visualised in Fig. S1 in Online Resource 1 (Electronic Supplementary Material). For all model variants, the five organic contaminants with the largest contributions contributed a total of 67 to $91 \%$ of the overall burden of disease estimated with the respective model version. The top five organic contaminants for each model version (13 organic contaminants in total) were chosen for further analysis. The ranking of these organic contaminants per model variant is shown in Table S8 in Online Resource 1 (Electronic Supplementary Material), and the lowest and highest burden of disease estimated per individual contaminant are shown in Table 1.

\subsection{Burden of disease per capita per year}

So far, the burdens of disease were calculated as DALY per kilogram dry solids ( $\mathrm{kg}$ DS). In the municipality of Gothenburg, the sewage sludge production is approximately $23 \mathrm{~kg}$ DS per capita per year. The health burden associated with land application of sewage sludge estimated in this study can now be expressed as per capita annual health burden and compared with per capita annual health burdens caused by other risk factors. For metals, the lowest estimate based on the model variants investigated was 7.7E-04 DALY per capita per year; the highest estimate was 2.1E-03 DALY per capita per year. For organic contaminants, the lowest estimate based on the model variants investigated was 6.5E-08 DALY per capita per year; the highest estimate was 1.3E-07 DALY per capita per year. However, it needs to be kept in mind that neither was monitoring data regarding contaminant concentrations available for all contaminants potentially present in the 


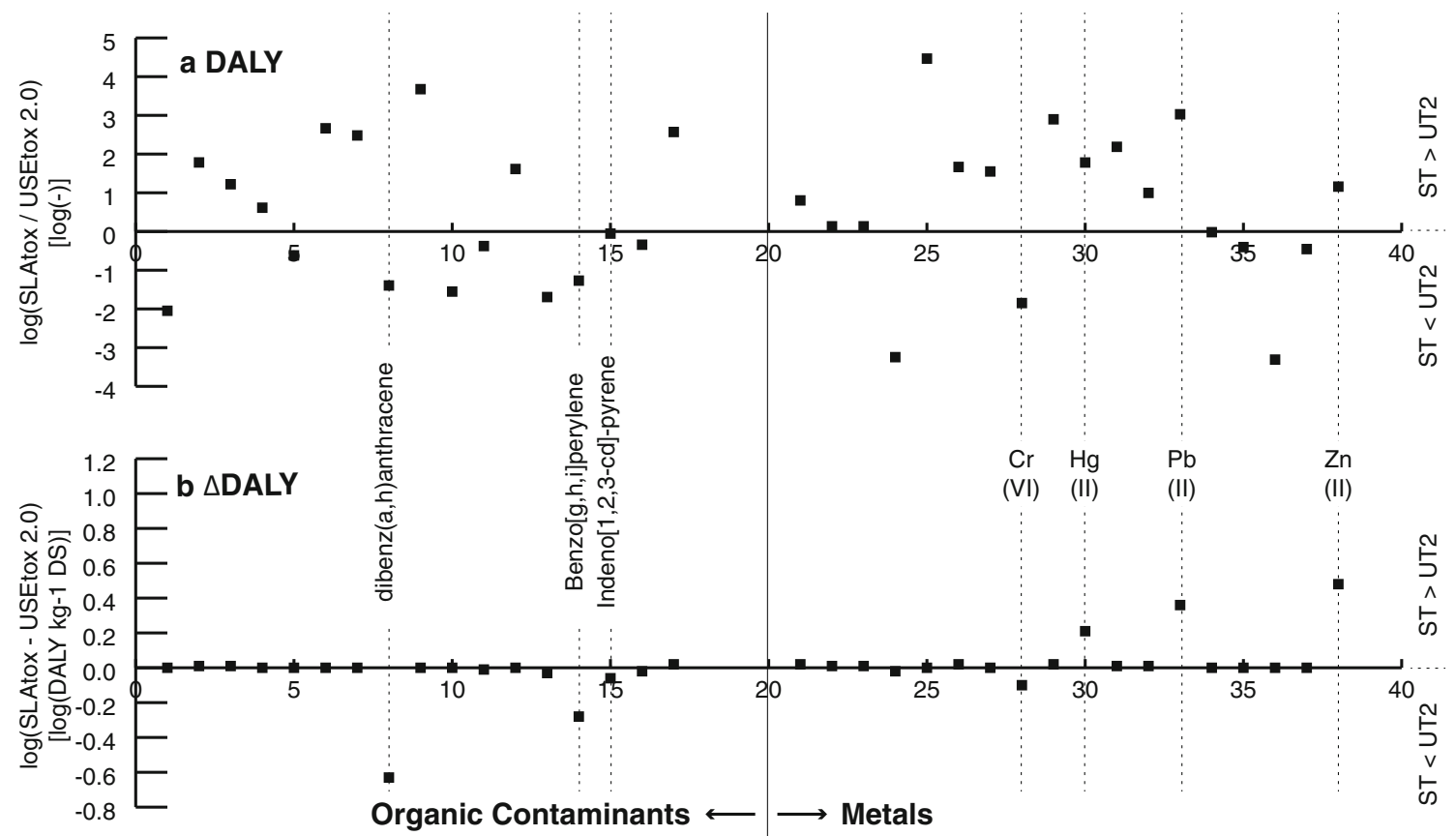

Fig. 6 Differences between the SLAtox model and the USEtox 2.0 model only for exposure pathways related to the consumption of aboveground and belowground produce (default parameterisation). Monitoring data for Gothenburg as well as other treatment plants in
Sweden was considered (i.e. $\mathrm{GBG}+\mathrm{SE}$ ). The respective values per individual chemical contaminant are ordered in the sequence of occurrence of the chemical contaminants in the USEtox 2.0 database
Table 1 Lowest and highest burden of disease estimated for 13 dominant organic contaminants through the different model variants investigated

\begin{tabular}{|c|c|c|c|c|}
\hline CAS & Chemical & Group & Low & High \\
\hline $117-81-7$ & DEHP & Phthalates & $\begin{array}{c}4.14 \mathrm{E}- \\
14\end{array}$ & $\begin{array}{c}2.11 \mathrm{E}- \\
11\end{array}$ \\
\hline $118-74-1$ & Hexachlorobenzene & Polychlorinated benzenes & $\begin{array}{c}3.39 \mathrm{E}- \\
12\end{array}$ & $\begin{array}{c}3.53 \mathrm{E}- \\
11\end{array}$ \\
\hline $\begin{array}{l}2385-85- \\
5\end{array}$ & Mirex & Biocides & $\begin{array}{c}3.11 \mathrm{E}- \\
12\end{array}$ & $\begin{array}{c}6.53 \mathrm{E}- \\
12\end{array}$ \\
\hline $50-32-8$ & Benzo[a]pyrene & $\begin{array}{l}\text { Polycyclic aromatic } \\
\text { hydrocarbons }\end{array}$ & $\begin{array}{c}1.92 \mathrm{E}- \\
12\end{array}$ & $\begin{array}{c}5.05 \mathrm{E}- \\
10\end{array}$ \\
\hline $57-63-6$ & Ethinylestradiol & Hormones & $\begin{array}{c}1.52 \mathrm{E}- \\
12\end{array}$ & $\begin{array}{c}4.73 \mathrm{E}- \\
10\end{array}$ \\
\hline $53-70-3$ & Dibenz(a,h)anthracene & $\begin{array}{l}\text { Polycyclic aromatic } \\
\text { hydrocarbons }\end{array}$ & $\begin{array}{c}2.90 \mathrm{E}- \\
13\end{array}$ & $\begin{array}{c}1.05 \mathrm{E}- \\
09\end{array}$ \\
\hline $\begin{array}{l}1163-19- \\
5\end{array}$ & $\begin{array}{l}\text { Decabromophenyl ether (PBDE } \\
\text { 209) }\end{array}$ & Brominated flame retardants & $\begin{array}{c}2.81 \mathrm{E}- \\
14\end{array}$ & $\begin{array}{c}1.74 \mathrm{E}- \\
12\end{array}$ \\
\hline $\begin{array}{l}1336-36- \\
3\end{array}$ & PCBs & Polychlorinated biphenyls & $\begin{array}{c}1.34 \mathrm{E}- \\
12\end{array}$ & $\begin{array}{c}8.48 \mathrm{E}- \\
12\end{array}$ \\
\hline $56-55-3$ & Benz[a]anthracene & $\begin{array}{l}\text { Polycyclic aromatic } \\
\text { hydrocarbons }\end{array}$ & $\begin{array}{c}1.45 \mathrm{E}- \\
11\end{array}$ & $\begin{array}{c}2.97 \mathrm{E}- \\
10\end{array}$ \\
\hline $193-39-5$ & Indeno[1,2,3-cd]-pyrene & $\begin{array}{l}\text { Polycyclic aromatic } \\
\text { hydrocarbons }\end{array}$ & $\begin{array}{c}1.54 \mathrm{E}- \\
11\end{array}$ & $\begin{array}{c}6.01 \mathrm{E}- \\
10\end{array}$ \\
\hline $205-99-2$ & Benzo[b]fluoranthene & $\begin{array}{l}\text { Polycyclic aromatic } \\
\text { hydrocarbons }\end{array}$ & $\begin{array}{c}7.57 \mathrm{E}- \\
11\end{array}$ & $\begin{array}{c}1.46 \mathrm{E}- \\
09\end{array}$ \\
\hline $207-08-9$ & Benzo[k]fluoranthene & $\begin{array}{l}\text { Polycyclic aromatic } \\
\text { hydrocarbons }\end{array}$ & $\begin{array}{c}3.02 \mathrm{E}- \\
10\end{array}$ & $\begin{array}{c}1.63 \mathrm{E}- \\
09\end{array}$ \\
\hline $208-96-8$ & Acenaphthylene & $\begin{array}{l}\text { Polycyclic aromatic } \\
\text { hydrocarbons }\end{array}$ & $\begin{array}{c}1.50 \mathrm{E}- \\
12\end{array}$ & $\begin{array}{c}1.35 \mathrm{E}- \\
11\end{array}$ \\
\hline
\end{tabular}


sludge nor were human health EFs available for all of the contaminants with available monitoring data.

\subsection{Accidental ingestion of treated sewage sludge}

If treated sewage sludge were accidentally ingested, in order to obtain a disease burden equal to the one estimated through the USEtox and SLAtox models (for metals and organic contaminants, respectively), the iF would need to be $1.6 \%$ for metals and $35 \%$ for organic contaminants. The production of treated (dewatered) sewage sludge in Gothenburg (the wastewater treatment plant treats the wastewater of 650,000 person equivalents) amounts to roughly $57,000 \mathrm{t}(15,000 \mathrm{t} \mathrm{DS})$ per year. Given above iFs, for metals, this would mean that an ingestion of $900,000 \mathrm{~kg}$ of treated sewage sludge would lead to the same burden of disease as the one estimated through the USEtox and SLAtox models (for metals and organic contaminants). For organic contaminants, the respective amount would be $20,000 \mathrm{t}$ to reach the same burden of disease as the one estimated through the USEtox and SLAtox models (for metals and organic contaminants). To get to the same disease burden only for organic contaminants, 40 to $100 \mathrm{~kg}$ of sludge would need to be ingested (depending on the model variant).

\section{Discussion}

Rather than performing a complete LCA study of various possible sewage sludge management options, this study focussed on LCIA for one impact category, human toxicity potential, and investigated the effect of modelling choices when assessing one given sewage sludge management option, the application of sewage sludge to agricultural land. More specifically, this study investigated whether the results obtained using the two USEtox versions (i.e. the USEtox 1.01 and USEtox 2.0 models) differ significantly from each other. This study also examined whether an alternative fate and exposure model for exposure through agricultural produce (i.e. the SLAtox model) leads to significantly different results than the respective generic fate and exposure models in the USEtox models.

\subsection{Priority contaminants}

The metals of concern found in previous RA studies (VKM 2009; Sternbeck et al. 2013) are cadmium (Cd), copper (Cu), mercury $(\mathrm{Hg})$ and zinc $(\mathrm{Zn})$. In this study, chromium $(\mathrm{Cr})$, mercury $(\mathrm{Hg})$, lead $(\mathrm{Pb})$ and zinc $(\mathrm{Zn})$ were found to be the elements of most concern from the perspective of the overall impact associated with the exposure of a whole population (see Table 2). If most chromium were present as $\mathrm{Cr}$ (III), rather
Table 2 Metals of concern in the present and other studies

\begin{tabular}{lllllll}
\hline & Cadmium & Chromium & Copper & Mercury & Lead & Zinc \\
\hline & $(\mathrm{Cd})$ & $(\mathrm{Cr})$ & $(\mathrm{Cu})$ & $(\mathrm{Hg})$ & $(\mathrm{Pb})$ & $(\mathrm{Zn})$ \\
Present study & & $\mathrm{x}$ & & $\mathrm{x}$ & $\mathrm{x}$ & $\mathrm{x}$ \\
$\begin{array}{l}\text { VKM (2009) } \\
\text { Sternbeck et al. } \\
(2013)\end{array}$ & $\mathrm{x}$ & & & $\mathrm{x}$ & & \\
\hline
\end{tabular}

than the assumed 50:50 split between the two oxidation states, chromium would be of a lesser concern. The 13 organic contaminants of most potential concern from the perspective of the overall impact associated with the exposure of a whole population are the ones previously presented in Table 1. However, it should be kept in mind that the metals and organic chemicals that appeared to be dominant in this study are dominant only within a subset of the contaminants potentially present in sewage sludge (see Sect. 4.3).

\subsection{Relevance of accidental ingestion of treated sewage sludge}

Westrell et al. (2004) performed a quantitative microbial risk assessment for a Swedish wastewater treatment plant with sewage sludge application on agricultural land and assumed that two workers would each ingest $2 \mathrm{~g}$ of treated sewage sludge on 30 occasions per year. This corresponds to $120 \mathrm{~g}$ of sewage sludge ingested per year for the treatment plant with a capacity of 28,600 person equivalents considered by Westrell et al. (2004) or $2.7 \mathrm{~kg}$ per year for a treatment plant with a capacity of 650,000 person equivalents. If the assumptions made by Westrell et al. (2004) were representative for the wastewater treatment plant in Gothenburg, for organic contaminants, the disease burden associated with accidental ingestion of sewage sludge would be one order of magnitude smaller than the disease burden estimated based on the USEtox and SLAtox models (for organic contaminants only), for metals even six orders of magnitude smaller.

\subsection{Uncertainties}

When it comes to the estimation of an aggregated burden of disease associated with contaminants contained in sewage sludge applied to agricultural land, there are several sources of uncertainty. Three are discussed here.

\subsubsection{Model adequacy}

Every model is a conceptualisation of the real world, but this does not necessarily mean that every model is an accurate reflection of reality. Which of the model variants best reflects reality is difficult to determine. In fact, it may even be the case 
that none of the model variants is a good reflection of reality. For instance, a 30-year field study conducted in Sweden (Andersson 2012) concluded that repeated application of sewage sludge to agricultural land did not increase the uptake of metals for the crops investigated (i.e. wheat, barley, rapeseed and sugar beets). Thus, in comparison with field measurements, the human toxicity potential for metals estimated through any of the model variants investigated in the present study would appear to be an overestimation.

\subsubsection{Data gaps regarding contaminant concentrations in sewage sludge}

The monitoring data underlying this study may not cover all contaminants present in the sludge. We attempted to close data gaps to a certain extent by considering monitoring data from other Swedish wastewater treatment plants for the concentrations of organic contaminants where no monitoring data were available for Gothenburg. Depending on the model variant, this increased the overall burden of disease estimate by a factor of 1.1 to 1.7. Still, there is a range of other contaminants present in the sludge that were not covered by any of the monitoring data underlying the present study.

\subsubsection{Data gaps regarding chemical and biological properties of contaminants}

Chemical and biological properties of contaminants were available only for about a fifth of the contaminants for which monitoring data on contaminant concentrations in sewage sludge were available. The aggregated burden of disease estimate would be larger if chemical and biological properties were available for more contaminants. For instance, the availability of human health EFs for 12 additional organic contaminants in the USEtox 2.0 model increased the aggregate burden of disease estimate by a factor of 1.7 to 4.1 compared with the USEtox 2.0 model results for only those organic contaminants where EFs are available in the USEtox 1.01 model ( $\Sigma 106$ versus $\Sigma 94$ in Table S5 in Online Resource 1, Electronic Supplementary Material). Also, as only cancer EFs were available for these additional contaminants, cancer effects dominated the aggregated burden of disease in the USEtox 2.0 model.

\subsection{Robustness of the results}

\subsubsection{Representativeness of results for other locations and points in time}

This study was based on monitoring data for sewage sludge produced at the wastewater treatment plant in Gothenburg (years 2012-2014), which was complemented with monitoring data from other treatment plants in Sweden (years 2000
2013). Over the past years, the treatment plant operator in Gothenburg aimed to disconnect industrial discharges by having large industrial polluters build their own wastewater treatment plants. In a context where there are more industrial discharges reaching the municipal wastewater treatment plants or where legislation regarding the use of certain chemicals is different, the results might be different.

\subsubsection{Sensitivity towards data gaps}

The aggregate burden of disease for metals was dominated by four influential metals out of 15 for which sufficient data were available for the calculations. The aggregated burden of disease for organic contaminants was dominated by five influential organic contaminants out of a maximum of 106 for which sufficient data were available for the calculations (note that the five dominant organic contaminants were different for the different model variants, though with a certain overlap, see Table S7 in Online Resource 1 (Electronic Supplementary Material)). The dominance of a few contaminants indicates a distribution where one single contaminant can have a large contribution to the aggregate impact. The USEtox 2.0 manual (Fantke et al. 2015) recommends that the reliability of the chemical-specific input data be verified for substances that turn out to dominantly contribute to the impact scores for toxicity. Our study reinforces the importance of this recommendation but also shows that it only addresses part of the challenge. Whether the contaminants that proved dominant indeed are the worst contaminants potentially present in sewage sludge is inherently difficult to anticipate. For metals, this is somewhat less of a problem because the number of different metals is finite and because the estimations made in this study may have been overestimations in comparison with field measurements. For organic contaminants, more caution seems to be warranted. For instance, Scheringer et al. (2012) suggested that there are between 190 and 1200 persistent organic pollutants to be expected for future evaluation under the Stockholm Convention on Persistent Organic Pollutants. This means that one of these organic contaminants may have an impact at least as dominant as the worst organic contaminant considered in this study. Finally, there is also the issue of organometallic compounds, for which monitoring data as well as chemical and biological data are scarce.

\subsubsection{Sensitivity towards assumptions and problem framing}

Recent risk assessment studies in the Nordic countries concluded that the application of sewage sludge to agricultural land generally constitutes a low risk to consumers (Diana et al. 2011; Sternbeck et al. 2013; VKM 2009). Yet, there has been considerable opposition against the practice of land application. This opposition may be a result of the intrinsically subjective nature of risk perception (Ropeik 2012). Also, 
several authors (e.g. Wynne 1992; Hoffmann-Riem and Wynne 2002; Saltelli et al. 2013; Giampietro and Bukkens 2015) point out the importance of critically reflecting upon the (often implicit) pre-analytical assumptions underlying a certain approach. The knowledge obtained through a given approach thus always is conditional and depends on whether the pre-analytical assumptions turn out to be valid (Wynne 1992).

\section{Conclusions}

Many municipalities are facing increasing pressure to adapt waste management infrastructure in order to better close nutrient cycles. Regarding wastewater infrastructure, one option to close carbon and nutrient cycles is the application of sewage sludge to agricultural land. The different LCIA models to quantify human toxicity potential of contaminants present in sewage sludge applied to agricultural land that were investigated (i.e. USEtox 1.01, USEtox 2.0, SLAtox) provided burden of disease estimates different from one another for individual contaminants. For the aggregated burden of disease, however, the results obtained through the different model variants investigated were on the same order of magnitude. This may not come as big surprise given that the different model variants were based on the same set of contaminants, similar chemical and biological data and similar principles regarding fate and exposure modelling. These findings encourage decision-makers to have some confidence that the technical information they get by using different model variants to model human toxicity in LCA is on the whole consistent. Given this consistency, refining LCIA models for human toxicity and developing LCIA models specifically targeted to land application of sewage sludge seem less important, at least for routine exposure through agricultural produce. Furthermore, in light of the data gaps (i.e. incomplete monitoring data, lack of human health EFs), more monitoring data and human health EFs would be useful.

Given that no health effect has been observed in connection to land application of sewage sludge, it is not possible to validate the three models examined in this paper and to make an absolute recommendation regarding which is superior. Nevertheless, some similarities and differences between the models have been identified in this paper. We hope that this work will contribute to the future development of LCIA for wastewater systems and discussion around the appropriate applications of LCA approaches. Given the uncertainties associated with the assessment of human toxicity in LCA, it may be indicated to contemplate the extent to which LCA in general is capable of informing the sewage sludge debate when it comes to human toxicity and possibly also other indicators. Future research should also aim to identify which types of questions of interest in the debate about how to manage sewage sludge can be answered by LCA and which types of questions cannot.

Acknowledgments This project has received funding from the Swedish Research Council for Environment, Agricultural Sciences and Spatial Planning (FORMAS) under grant agreement no. 2012-1122. The authors would also like to thank David I'Ons (Gryaab AB) for the assistance with data collection regarding contaminants in the sewage sludge of Gothenburg, Sweden.

Open Access This article is distributed under the terms of the Creative Commons Attribution 4.0 International License (http:// creativecommons.org/licenses/by/4.0/), which permits unrestricted use, distribution, and reproduction in any medium, provided you give appropriate credit to the original author(s) and the source, provide a link to the Creative Commons license, and indicate if changes were made.

\section{References}

Andersson P-G (2012) Slamspridning på åkermark. Fältförsök med kommunalt avloppsslam från Malmö och Lund under åren 19812011

Bengtsson M, Tillman A-M (2004) Actors and interpretations in an environmental controversy: the Swedish debate on sewage sludge use in agriculture. Resour Conserv Recy 42:65-82

Diana L, Frankki S, Gustavson K, Sternbeck J (2011) Using sludge on arable land-effect based levels and long-term accumulation for certain organic contaminants. Nordic Council of Ministers, Copenhagen ISBN 978-92-893-2194-5

EC (2010) The International Reference Life Cycle Data System (ILCD) Handbook - General guide for Life Cycle Assessment—Detailed guidance. European Commission, Joint Research Centre. Publications office of the European Union, Luxemburg

ECB (2003) European Commission Technical Guidance Document on Risk Assessment

Fantke P (Ed.), Huijbregts M, Margni M, Hauschild M, Jolliet O, McKone TE, Rosenbaum RK, van de Meent D (2015) USEtox ${ }^{\circledR}$ 2.0 User Manual (Version 2), http://usetox.org

Giampietro M, Bukkens SGF (2015) Quality assurance of knowledge claims in governance for sustainability: transcending the duality of passion vs. reason. Int J Sustain Dev 18(4):282-309

Heimersson S, Harder R, Peters GM, Svanström M (2014) Including pathogen risk in life cycle assessment of wastewater management. 2. Quantitative comparison of pathogen risk to other impacts on human health. Environ Sci Technol 48(16):9446-9453

Hoffmann-Riem H, Wynne B (2002) In risk assessment, one has to admit ignorance. Nature 416:123

Hospido A, Carballa M, Moreira M, Omil F, Lema JM, Feijoo G (2010) Environmental assessment of anaerobically digested sludge reuse in agriculture: potential impacts of emerging microcontaminants. Wat Res 44:3225-3233

Kobayashi Y, Peters GM, Ashbolt NJ, Heimersson S, Svanström M, Khan SJ (2015) Global and local health burden trade-off through the hybridisation of quantitative microbial risk assessment and life cycle assessment to aid water management. Wat Res 79:26-38

Lane JL, de Haas DW, Lant PA (2015) The diverse environmental burden of city-scale urban water systems. Wat Res 81:391-415

Lim SR, Lam CW, Schoenung JM (2011) Priority screening of toxic chemicals and industry sectors in the U.S. toxics release inventory: a comparison of the life cycle impact-based and risk-based 
assessment tools developed by U.S. EPA. J Environ Manage 92: $2235-2240$

Mattila T, Verta M, Seppälä J (2011) Comparing priority setting in integrated hazardous substance assessment and life cycle impact assessment. Int J Life Cycle Assess 16:788-794

Muñoz I, Gómez MJ, Molina-Díaz A, Huijbregts MAJ, Fernández-Alba AR, García-Calvo E (2008) Ranking potential impacts of priority and emerging pollutants in urban wastewater through life cycle impact assessment. Chemosphere 74:37-44

Murray C (1994) Quantifying the burden of disease: the technical basis for disability-adjusted life years. B World Health Organ 72:429-445

Nakakubo T, Tokai A, Ohno K (2012) Comparative assessment of technological systems for recycling sludge and food waste aimed at greenhouse gas emissions reduction and phosphorus recovery. J Cleaner Prod 32:157-172

Naturvårdsverket (2015) Miljöövervakningsdata. Screening av miljögifter. [Environmental monitoring data. Screening of environmental contaminants.] Swedish Environmental Protection Agency. http://dvss.ivl.se/DataSelect.aspx (accessed 2 June 2015)

Peters G, Sack F, Lenzen M, Lundie S, Gallego B (2008) Towards a deeper and broader ecological footprint. Engineering Sustainability 161(1):31-37

Ropeik D (2012) The Perception Gap: recognizing and managing the risks that arise when we get risk wrong. Food Chem Toxicol 50: $1222-1225$

Rosenbaum RK, Bachmann TM, Gold LS, Huijbregts MAJ, Jolliet O, Juraske R, Koehler A, Larsen HF, MacLeod M, Margni M, McKone TE, Payet J, Schuhmacher M, van de Meent D, Hauschild MZ (2008) USEtox - the UNEP-SETAC toxicity model: recommended characterisation factors for human toxicity and freshwater ecotoxicity in life cycle impact assessment. Int J Life Cycle Assess 13:532-546

Rosenbaum RK, Huibregts MAJ, Henderson AD, Margni M, McKone TE, Van de Meent D, Hauschild MZ, Shaked S, Li DS, Gold LS,
Jolliet O (2011) USEtox human exposure and toxicity factors for comparative assessment of toxic emissions in life cycle analysis: sensitivity analysis to key chemical properties. Int J Life Cycle Assess 16:710-727

Sablayrolles C, Gabrielle B, Montrejaud-Vignoles M (2010) Life cycle assessment of biosolids land application and evaluation of the factors impacting human toxicity through plant uptake. J Ind Ecol 14(2):231-241

Saltelli A, Guimarães Pereira Â, Van der Sluijs JP, Funtowicz S (2013) What do I make of your latinorum? Sensitivity auditing of mathematical modelling. Int J Foresight and Innovation Policy 9(2/3/4): 213-234

Scheringer M, Strempel S, Hukari S, Ng CA, Blepp M (2012) How many persistent organic pollutants should we expect? Atm Poll Res 3: 383-391

Sternbeck J, Österås AH, Allmyr M (2013) Riskbedömning av fosforrika fraktioner vid återförsel till åker-och skogsmark samt vid anläggande av etableringsskikt

VKM (2009) Risk assessment of contaminants in sewage sludge applied on Norwegian soils-opinion of the Panel on Contaminants in the Norwegian Scientific Committee for Food Safety

Westrell T, Schönning C, Stenström TA, Ashbolt NJ (2004) QMRA (quantitative microbial risk assessment) and HACCP (hazard analysis and critical control points) for management of pathogens in wastewater and sewage sludge treatment and reuse. Water Sci Technol 50(2):23-30

Wynne B (1992) Uncertainty and environmental learning - reconceiving science and policy in the preventive paradigm. Global Environ Chang 2(2):111-127

Yoshida H, Clavreul J, Scheutz C, Christensen TH (2014) Influence of data collection schemes on the life cycle assessment of a municipal wastewater treatment plant. Water Res 56:292-303 